\title{
The Research on Development Initiatives for Private Basic Education Schools
}

\author{
Victor Corbito Cabrera \\ Department Head, San Antonio National High School, Makati City, Philippines
}

\section{Email address:}

vrice1225@yahoo.com

\section{To cite this article:}

Victor Corbito Cabrera. The Research on Development Initiatives for Private Basic Education Schools. Science Journal of Education. Vol. 5, No. 4, 2017, pp. 136-143. doi: 10.11648/j.sjedu.20170504.12

Received: March 2, 2017; Accepted: April 18, 2017; Published: May 4, 2017

\begin{abstract}
The emerging needs of private basic education schools have been the issue of the school administrators in terms of development. The schools always embrace the new paradigm of teaching and learning for the betterment of the students and the school as well. Along the management of the school are the situations and problems that are crucial to the development. Hence, this study aimed to determine the descriptions and problems of the sampled private basic education schools as bases in preparing a five-year continuing development program. Descriptive-comparative method of research was utilized to obtain the information needed in this study. Mann Whitney U-test was also used to determine the difference of the responses of the administrators and teachers. Interviews were conducted to substantiate the information needed and to further validate the variables mentioned in the questionnaire-checklist. A questionnaire-checklist was used to obtain the data and findings describing the private basic education schools in terms of administration, curriculum, faculty, goals and objectives, student personnel services, library, human and physical resources, laboratory, and SOCI (Social Orientation and Community Involvement). Likewise, it was also through the questionnaire-checklist that the problems encountered by the respondents were assessed. These encountered problems were on enrollment, faculty, facilities, library resources, linkages, Social Orientation and Community Involvement, instructional materials, NAT (National Achievement Test) performance, and accreditation preparation. Hence, the offered solutions on the cited problems were also assessed. These teacher and administrator-respondents aspired to produce excellent students and build a strong foundation of basic education schools that would be globally competitive in all areas of learning and operations. Hence, a Five-year Continuing Development Program was prepared and hereby recommended.
\end{abstract}

Keywords: Development Initiatives, NAT (National Achievement Test), Private Basic Education Schools, Research-Made Checklist, SOCI (Social Orientation and Community Involvement), DepEd (Department of Education)

\section{Introduction}

Schools consider the increasing population of the children of school-age as one of the challenges that must be given attention and solution. Also, the Philippines is included in the top 5 countries with 1.5 million out-of-school children as stated by UNESCO in 2011 (Panorama, 2015). For the government to eventually solve the issue of the growth of the students' population, highlights the considerations on classroom needs, expansion of school buildings, and conversion of annexes to independent schools. On the other hand, private institutions have their counterparts in defining the goals and objectives of educating the youth, and therefore anchored to many programs and projects of the DepEd
(Department of Education). Moreover, the school system is facing a vast changing transformation of both curriculum and administration. Private schools are encouraged to do reforms and paradigm shifts where improvement is the main concern. Policies and mandates of private schools are aligned with the DepEd's regulations as stated in the "Batas Pambansa Blg. 232 [1]" Therefore, all private schools shall abide by the directives in securing government permit to operate.

One of the major functions of a School Head is to secure government permit to operate or recognition from the Department of Education. Schools thereby receive the certificate of recognition if standards and all qualifications are met. The drive to secure this recognition from the government is the goal of the school owners and the school heads. The recognition 
serves as the school's powerful tool to have a better number of enrollees. Here comes in the opportunity of the private schools to accommodate the influx of the students' population.

The growth of today's private schools is greater in than the past years. It is noted that the number of private schools is competitive with the public schools in terms of curriculum implementation, instructional materials, and human resource. Further, Montessori schools and other private basic institutions seek to address the problem of displacements. Private schools of today support the increasing demands of curriculum transformation. This transformation is anchored on the fast changing classroom scenario where computer aided instruction must be ready. Improvement from basic instructional materials to technological classroom setting is encouraged to further improve the teaching and learning process. Globally competitive schools ensure the students' academic achievement. As observed in our country, our students compete with other countries in spite of the limited technological resources both in academic and non-academic skills. These global difficulties on education reform may not be a hindrance to reach the peak of the school's vision and mission whose main objective is anchored on the vast changing educational development. Hence, the educational development for greater students' comprehensive achievement is what every private school is aiming for. As discussed during the World Education Forum in Dakar Senegal last April 2000 (SEAMEO ICXELS, 2012) that governments have an obligation to ensure the "Education for All" goals and targets must be reached and sustained. It has been discussed that the cooperation of all educational leaders must be observed and no children, young people, and adults must be left behind. It is therefore the reaffirmation of every educational leader to tap each individual's talents and potential, and develop learners' personalities so that they can improve their lives and transform societies into progressive communities.

The private basic education institutions have experienced continuing population increase. With this growth, some schools have decided to open in response to the graduates' and other neighboring public schools' clamor in the nearby communities, for branches and expansions. This will help parents to send their children to school that is already within their community.

Elementary graduates from public schools, likewise, will not experience difficulties in adjusting to a new environment. Furthermore, these private basic institutions believe that continuing education is necessary for its teachers and students to keep abreast of the new trends in teaching and learning to be globally competitive. Thus, the schools send teachers, staff, and students to different seminars for development programs. The performance of the school administrators in seminars and workshops serve as the benchmarks of the school's performance to find out whether targeted institutional goals and policies are accomplished. Hence, performance, accomplishments, and other capacities for development need to be reviewed and polished to actualize responsibilities of a competitive school.

On the other hand, private basic institutions experience shortage of classrooms. Portions of the schools have been converted to other important educational rooms and other functional offices. Though the schools have furnished educational materials and equipment; there is still a need to produce more instructional materials for better implementation of effective instruction. It is also observed that there is a continuous population increase in terms of enrollment. The accommodation of these expected children of school-age is quite a problem to most of the public and private schools.

Thus, the stated issues, concerns, and problems in running a school clearly defines the role of the school administrators to ensure the expected remedy, solutions, and recommendation to the paradigm shifts of school improvement.

\section{Materials and Methods}

\subsection{Statement of the Problem}

The study aimed to determine the development initiatives of private basic education schools as bases in preparing the continuing development program.

The study sought answers to the following questions:

(1) How may the development initiatives of the sampled private basic education institutions be described in terms of:

a. administration,

b. curriculum,

c. faculty,

d. goals and objectives,

e. student personnel services,

f. library,

g. resources (human and physical),

h. laboratories, and

i. social orientation and community involvement?

(2) What challenges are encountered in the operation in the areas of:

a. enrolment,

b. selection of Faculty,

c. facilities,

d. library resources,

e. linkages,

f. SOCI Social Orientation and Community Involvement,

g. Instructional Materials,

h. NAT Performance, and

i. accreditation preparation?

(3) What solutions may be offered to facilitate remedy to the cited challenges?

(4) Is there significant difference between the responses of the administrators and teachers in terms of development initiatives?

(5) Based from the findings, what development initiatives maybe considered included in the Five-year Continuing Development Program and may be crafted for private basic education institutions?

\subsection{Methods of Research}

The nature of the study is descriptive-comparative. It is descriptive in nature because it shows information regarding the selected administrators and teachers in the Division of 
Taguig and Pateros, Makati City, and Quezon City. Comparative method is used to determine the differences between two groups of individuals, the administrators and the teachers. On the other hand, descriptive method is an instrument to describe the findings through a narrative description of some sort (Fraenkel and Wallen, 1994). It is also a form of summary that is essential to interpret the data collected (Downie and Heath, 1984). Descriptive method of research is used to explain the figures and the situations collected from the interview that will be clarified in a form of analytical narration (Lexicon, 1989).

The study made use of the qualitative-comparative approaches through survey research where facts from the group of administrators and teachers were gathered to evaluate the status of the data. Mann Whitney U-test was also used to determine the difference of the responses of the administrators and teachers. The quantitative data showed the variables being studied through the use of a scale.

\subsection{Data Analysis}

The data were collected, tabulated, and analyzed using the following statistical treatment:

a. Percentage was used to determine the percentage of the respondents' data of their Profile.

b. Ranking was used to determine the most predominant practice. The biggest percentage is given the rank 1, rank 2 as the second, and so on.

c. Mann Whitney U-test was used to determine the difference between the responses of the administrators and teachers. This is a non-parametric test when the data fails to comply with the normality test and sizes of groups differ greatly. Mann Whitney U-test is the alternative test to the independent sample t-test. It is used to compare two population means that come from the same population, it is also used to test whether two population means are equal or not. For this test, the Statistical Package for Social Sciences (SPSS) is used to interpret and compute the data gathered.

$\mathrm{d}$. The weighted average was used to determine the degree of seriousness of the descriptions of the schools identified by the elected administrators and teachers of the private basic education institutions.

e. The 5-point Scale of Statistical value was used in this study specifically for the challenges encountered in the operation of the schools identified by the selected administrators and teachers.

\section{Results \& Discussion}

\subsection{Description of the Private Basic Education Schools}

The descriptions of the private basic education schools as to administration, curriculum, faculty, goals and objectives, student personnel services, library, resources, laboratories, social orientation and community involvement are reflected in table 1 .

Table 1. Description of the Development Initiatives of Private Basic Education Institutions.

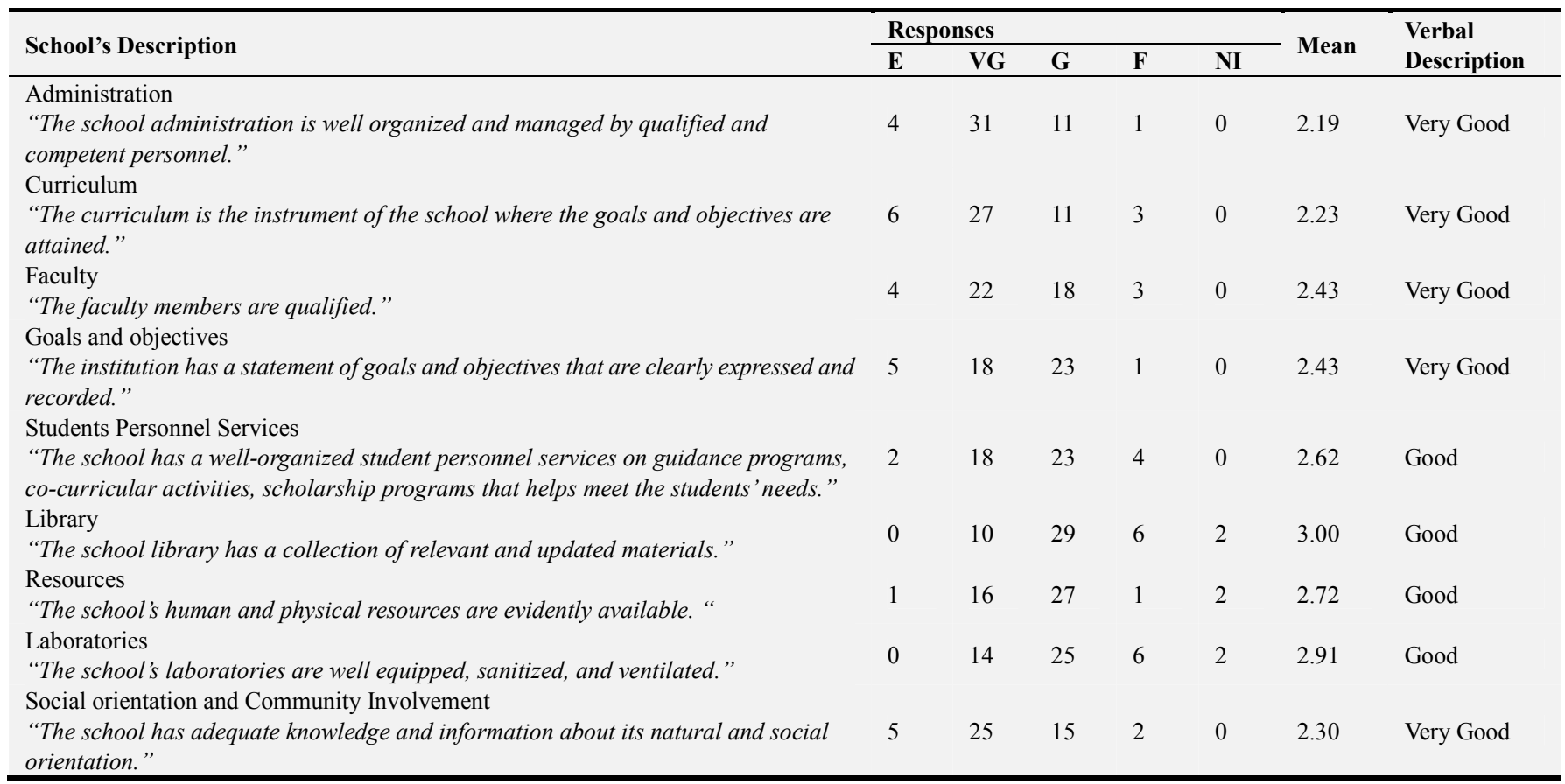

Legend: 1.00-1.49 - Excellent (E); 1.50-2.49 - Very Good (VG); 2.50-3.49 - Good (G); 3.50-4.4.49 - Fair (F); 4.50-5.00 Needs Improvement (NI)

\subsubsection{Administration}

According to some teachers who were interviewed, the educational qualification of the school's administrators fit with the functions they are handling. They show accountability with all the school's responsibility and endeavor. Brundrett and Rhodes (2011) explained that leading and managing the school is not only an attempt for 
improvement but also accountability for all the stakeholders. School administrators are responsible to all the school's achievement of both the students and the teachers. They are liable to the downfall and success of the school.

\subsubsection{Curriculum}

As per the result of the interview with the teachers and the administrators, the curriculum being used as adapted from the DepEd is very relevant and instrumental to the development of the school. It is further explained during the interview that additional and modified curriculum is also used for the enhancement of the academic goal and attainment of the national objectives in education. These modified curriculums are best guide programs to ensure the students' multi-level of learning through the use of materials and other educational resources. According to Rodger (2012), Montessori curriculum is best described and used to further improve the students' academic growth and stimulate the children's interest through self-directed activities.

\subsubsection{Faculty}

It is highlighted during the interview with the school administrators that the faculty members are very good with regards to their performance and qualification. These faculty members, according to the administrators, are pursuing continuing education and better prepared with additional trainings and seminars that lead to their professional growth.

Furthermore, the school administrators have some contributions in leading the teachers to pursue higher education. They may be the encouraging factors that influence the teacher to upgrade the professional responsibilities in school. The new teachers are somehow unaccustomed in the management of teaching and learning process in classroom. Therefore, the administrators are in charge of guiding these teachers to a betterment of the teaching profession. According to Gray and Smith (2009), the school administrators must remember that the new teachers are unfamiliar with the role expectations of their position and need as much detailed information as they can receive. One of the responsibilities of the leader is to direct the teachers to professional growth and monitor the academic advancement of the students.

\subsubsection{Goals and Objectives}

It was distinctly explained during the discussion with the respondents that goals and objectives are expressed and recorded but not clearly stated or vice versa.

The data mean that the goals and objectives must be set according to the need of the community and are aligned with the DepEd's mission and vision. According to Moravcik et al. (2013), all curriculum is based on a vision of society, values, a philosophy, a particular view of learners and teachers, and the ways educators translate this vision into learning experiences.

\subsubsection{Student Personnel Services}

Almost half of the respondents described the student personnel services as good. The data mean that the student personnel services are only in the middle of its functions where some areas of services must be given attention to fully implement and therefore of great help to students' performance in both academic and co-curricular growth. Similarly, the guidance programs are effective platforms of students' advancement. These programs may clearly define the students' needs and assistance and be the vehicles in pursuing their career.

\subsubsection{Library}

It is noted that the big number of respondents described the library as good. The number of respondents also shows that the library has limited materials and references. The teacher-respondents discussed during the interview that there is a shortage of library holdings. The Internet connectivity is very slow and sometimes not working. The Filipiniana section is not evident. Thus, the problem on library holdings is the most major issue of some schools.

\subsubsection{Resources}

The schools have problems on resources as it is shown in the gathered data reflected by the big number of respondents who described the school's resources as good. It is a common problem of the school owners and administrators, as noted during the interview, that human and physical resources are the distinctive issues in running the school. The schools may experience lack of teachers even in the middle of the school year. Tapping people for every programs and projects may be considered the normal situation in school where some people are needed. Ginnette et al. (2013), discussed that the school is a team that needs to have clear vision on programs, projects, and activities where human and physical resources are needed for the best accomplishment.

\subsubsection{Laboratories}

The gathered data show almost half of the respondents described the school's laboratories as good. It is an indication that most of the private schools have difficulty in putting up laboratory equipment. Problems on school's laboratories are about the purchase of some apparatus, scientific equipment, and other materials that are needed in the operation of the school as discussed and manifested by the teacher-respondents during the interview.

\subsubsection{Social Orientation and Community Involvement}

The number of respondents tells how the schools are oriented and involved in the community's programs, projects, and activities. Some private basic institutions are considered performing not only on the students' academic achievement but more so on the involvement in the programs of the community. This is similar to most schools that the awareness on social orientation and community involvement is very evident. It is one of the reasons to let the school be known to the community. The community acknowledges the performance of the school's welfare, service, and assistance.

\subsection{Challenges Encountered by the Respondents}

The data mean that the five problems that are cited really encountered by the private basic institutions. These problems are common to private schools as discussed by some administrators 
who were interviewed. These problems that are noted as very serious must be given immediate attention to discuss the remedy and arrive at the solution that could benefit both the parents of the enrolling student and the school. Problems on procedure on enrollment and class schedule should also be given close attention. Some teachers experienced these problems during the enrollment where volume of unexpected enrollees is present. There must be a modification on the procedure on enrollment; and prepared class schedule must properly be posted during the enrollment. It is stipulated in the DepEd Student's Diary (2015) that all requirements must be brought to the enrolling officer during the enrollment period.

The most problem of the schools on the selection of the faculty is about the poor oral and written communication and the negative attitude of the application. It is a common observation of the school administrators during the interview with the teacher-applicants that there must be a test for English Proficiency. The Schools' Division of the DepEd has conducted an English Proficiency test for teacher-applicants for public schools. DepEd Order No. 22, series of 2015 states about the hiring guidelines for teacher positions where the conduct of the English Proficiency Test is mandated. The purpose of this examination is to set the teachers to a more strict English communication skill. Hence, the issuance of the DepEd guidelines aims to integrate and further institutionalize the primary objective of the K to 12 Basic Education Program which is to enhance the overall quality of basic education in the country by hiring competent teachers.

There is really a problem on school's facilities where the school owners may not refute. It is a common observation on the schools that are starting to operate to have gradual improvement on facilities. Other schools have it as improved as it can be depending on the availability of the school's budget. All educational materials, facilities, and other school structure may be purchased and improved from the allocated budget. Students' tuition fee is the main source of the school to facilitate the problem on fiscal management. Sunga (2013), stressed out that the $20 \%$ of the tuition fee shall go to the improvement or modernization of buildings, equipment, libraries, laboratories, gymnasia and similar facilities, and to the payment of other costs of operation.

The problem on library resources is paralleled to the problem on facilities. These problems have something to do with the school's accountability on procurement and acquisition. The library is the heart of the school where researches and studies must be done; and therefore must have, if not complete, at least the very innovative and recent library materials. School owners must be familiar with the library's needs.

There's really a problem on school's linkages with the stakeholders. Miscommunication on the programs and projects is the main issue on school's problem on linkages. Stakeholders are the school's partners in promoting the goal of the school for students' welfare and assistance. The linkages' goal is to show the community the effectiveness, needs, and purpose of the school's programs and projects. Likewise, the academic achievement of the students is always the highlight of the purpose. The implementation of the programs and projects must be properly communicated and coordinated for a better result.

The main issue on social orientation is about unfit or misfit projects. The school introduces projects that may not be appropriate to the needs of the present situation. Although, the school distinctively prepares programs and projects for the purpose of being known to the community, the preparations may become useless due to lack of sufficient agenda and feasible studies. However, according to the administrators who were interviewed, programs and projects are properly prepared and implemented but still others are of negative response to the community. Apposite agenda of the program must be drafted by the members of the school board and eventually disseminated to the community or to the stakeholder concerned. Procurement of instructional materials must be given attention by the school owners and administrators. However, Sunga (2013) stressed out that a private school may receive grant, legacy, donation, gift, bequest or devise from any institution, individual, corporation, foundation, trust of philanthropic organization or research institution or organization. School's resources may come from other stakeholders by tapping for good purpose.

There is a problem on the students' NAT performance. National achievement test is a basis of the school's performance. However, there are instances that the students are not aware of said examination as manifested by the teachers who were interviewed. This situation results to low NAT performance. Interventions and other programs are innovations to set the students be prepared in taking the NAT.

The gathered data clearly presents the problem on the procurement of some library holdings and school facility. These problems may seriously be the difficulty on the application of the school's accreditation. Because of these problems, application on accreditation may be disapproved. Therefore, sufficient library holdings, instructional materials, and other school facilities must be upgraded and improved. Teachers' educational qualification must be given attention. Higher and appropriate educational attainment of the teachers is an indication of the school's improvement. Accredited schools may have the edge to have a productive enrollment. However, these problems on accreditation preparation can be remedied according to drafted solution and the status of the school as well. The problems should be identified and plan of action must be ready. According to Siccone (2012), problem identification is the most important and the most difficult phase of the process of solving. Even the most crucial phase of the preparation for the school's accreditation would be no hindrance in pursuing the accreditation level if listed and expected solutions are considered.

\subsection{Responses as Regards to Offered Solutions}

It is very evident that all offered solutions have gained above 50 percent choice of assessment of the respondents. The offered solutions are very feasible with the cited problems encountered by the schools. These solutions could be best for the problems encountered during the enrollment. Enrollment could be easier, refined, and systematic that both the school and the students will benefit.

The cited offered solutions are the best choice of assessment of the respondents. The school should follow the DepEd 
guidelines on hiring of competent teachers. Selection of teachers is one of the major tasks of the school administrators. Failure to do this task is a failure of the school as well. Labrador (2009) stated that quality education spells quality teachers and therefore quality learners. The product of proper selection of teacher is quality student.

The data obviously show that almost fifty percent of the respondents have chosen the cited offered solutions. Problems on school facilities cannot be denied. It shows that the offered solutions may bring to best result for the cited problems. It is an alarming situation to school owners that problems on facilities required an immediate and appropriate decision for better solutions. School facilities must be improved for students' curricular and non-curricular functions. The school facilities, therefore, must be used in accordance with all the activities, programs, and projects of the students. Hence, the school owners may then seek resources or support from other private and non-government institutions. Likewise, the school facilities may also be used by other public and private organizations for some reasons.

Almost all of the offered solutions on library resources are chosen by nearly 60 percent of the total respondents. Evidently, library resource is one of the serious problems of the schools where educational materials and other learning devices must be present. The school is obliged to have library. But somehow, according to some teachers who were interviewed, the library needs are not given full attention. The only resource for the library is the evaluation copies given by the publishing companies as manifested by these teachers.

However, there are instances that linkages may cause to none response of the stakeholders. According to Essex (2012), schools may be challenged on issues involving to awarding of free textbooks, transportations, tax credits, and auxiliary services. The reasons of these issues could be miscommunication, improper coordination to persons involved, and the inappropriate programs and projects that lead to wastage of preparation. Therefore, all stakeholders must know the preparations of appropriate programs and projects.
A school-community partnership provides opportunities for community members to support the improvement of student learning. Delgado (2009) cited that the role of the stakeholders is crucial in transforming the school into a safe and conducive learning environment. It is stressed out that the involvement of the DepEd leaders, school heads, teachers, students, parents, local elected officials, public and private agencies, youth development organizations, community development groups and business, civic and religious organizations will ensure the success of plans and activities.

School administrators must have the knowledge on how schools are financed. Purchasing instructional materials is one of the areas on fiscal management. There are various sources for school revenues to remedy the issues on instructional materials. Accepting donations, grants, and other means of generating fund for school's instructional materials is relevant to school management. Cordeiro and Cunningham (2013), explained that creating a meaningful and appropriate learning environment for students is a challenge for educators especially the issue on purchasing instructional materials that is important to students' academic achievement.

Administrators explained that NAT performance is the mirror of the school's performance. Academic performance is always given importance by schools. But on the contrary, some schools are striving and yet still in the bottom because most of the achievement level of the students' academic performance are insufficient. There are factors to consider why this academic achievement of the students is still beyond the expectations of the school administrators and the teachers. Importance of the NAT must be stressed out to students and parents. Further, low academic performance of the school is always the big issue in school, according to the teachers who were interviewed. According to them, it may also be a factor in their performance rating. Essex (2012), said that teachers might be liable to any punishment given to students who have received low performance in a particular subject area. Therefore, teachers are the source of the students' learning and they ensure the academic achievement of the students.

Table 2. Administrators' and Teachers' Responses to the Development Initiatives of Private Basic Education Schools.

\begin{tabular}{|c|c|c|c|c|c|c|c|c|}
\hline School's Description & Respondent & $\mathbf{N}$ & Mean & SD & z-value & df & p-value & Decision \\
\hline \multirow{2}{*}{ 1. Administration } & Administrators & 9 & 2.00 & 0.500 & \multirow{2}{*}{-1.050} & \multirow{2}{*}{45} & \multirow{2}{*}{0.294} & \multirow{2}{*}{ Accept } \\
\hline & Teachers & 38 & 2.24 & 0.634 & & & & \\
\hline \multirow{2}{*}{ 2. Curriculum } & Administrators & 9 & 2.00 & 0.707 & \multirow{2}{*}{-.940} & \multirow{2}{*}{45} & \multirow{2}{*}{0.347} & \multirow{2}{*}{ Accept } \\
\hline & Teachers & 38 & 2.29 & 0.768 & & & & \\
\hline \multirow{2}{*}{ 3. Faculty } & Administrators & 9 & 2.22 & 0.833 & \multirow{2}{*}{-.663} & \multirow{2}{*}{45} & \multirow{2}{*}{0.507} & \multirow{2}{*}{ Accept } \\
\hline & Teachers & 38 & 2.47 & 0.725 & & & & \\
\hline \multirow{2}{*}{ 4. Goals and objectives } & Administrators & 9 & 2.33 & 0.707 & \multirow{2}{*}{-.446} & \multirow{2}{*}{45} & \multirow{2}{*}{0.655} & \multirow{2}{*}{ Accept } \\
\hline & Teachers & 38 & 2.45 & 0.724 & & & & \\
\hline \multirow{2}{*}{$\begin{array}{l}\text { 5. Student personnel } \\
\text { services }\end{array}$} & Administrators & 9 & 2.67 & 1.000 & \multirow{2}{*}{-.208} & \multirow{2}{*}{45} & \multirow{2}{*}{0.835} & \multirow{2}{*}{ Accept } \\
\hline & Teachers & 38 & 2.61 & 0.638 & & & & \\
\hline \multirow{2}{*}{ 6. Library } & Administrators & 9 & 3.00 & 0.707 & \multirow{2}{*}{-.156} & \multirow{2}{*}{45} & \multirow{2}{*}{0.876} & \multirow{2}{*}{ Accept } \\
\hline & Teachers & 38 & 3.00 & 0.735 & & & & \\
\hline \multirow{2}{*}{ 7. Resources } & Administrators & 9 & 2.44 & 0.527 & \multirow{2}{*}{-1.370} & \multirow{2}{*}{45} & \multirow{2}{*}{0.171} & \multirow{2}{*}{ Accept } \\
\hline & Teachers & 38 & 2.79 & 0.777 & & & & \\
\hline 8 I ohoratorice & Administrators & 9 & 2.67 & 0.707 & & & & \\
\hline 8. Laboratories & Teachers & 38 & 2.97 & 0.788 & -1.059 & 45 & 0.290 & Accept \\
\hline 9. Social orientation and & Administrators & 9 & 2.00 & 0.500 & -1467 & 45 & 0143 & Accent \\
\hline community involvement & Teachers & 38 & 2.37 & 0.751 & $-1.40 /$ & 45 & 0.143 & Accept \\
\hline
\end{tabular}


Table 2 shows the result of Mann Whitney U-test. The result indicates no difference of the administrators' and teachers' responses in the development initiatives of private basic education schools.

As gleaned on the table, the area on library poses the highest level of p-value with 876, while the area on Social Orientation and Community Involvement posts the lowest level of p-value with 0.143 . Hence, the development on Social Orientation and Community Involvement is geared towards addressing such gap. On the other hand, while the responses of the administrators in the area on library have the highest $p$-value, the teachers' point of view seems otherwise. The table further shows that all items under school's description have greater p-values than the level of significance of 05 . Therefore, the null hypothesis indicating that there is no significant difference in the responses of the administrators and teachers in terms of development initiatives is accepted.

Moreover, the aforementioned descriptions of the private basic education schools explained that there are concerns in improving the schools. The development initiatives of the schools are the powerful tool in realizing the goals and objectives. The table also implies that both the school administrators and the teachers have the same foresight as to how the schools could be transformed into a developed, equipped, and globally competitive institutions of learning. The schools' descriptions also denote that the private basic education schools, if properly managed, could be internationally aligned to a curriculum that result into the students to be more highly competent employee in the global workforce. Manabat (2015), explained that the administrators and teachers gave the highest assessment that they strongly agree that the curriculum provides chance to higher level of study, learning, and teaching. It is also stressed in the study that a curriculum could convert a school to college and then to a university. The data also show that the cooperation of the administrators and the teachers could be the best improving-body for the success of the private basic education schools.

\section{Conclusion and Recommendation}

The description on the private basic institution on administration, curriculum, faculty, goals and objectives, and social orientation and community involvement is very good. The description on the private basic institution on students' personnel services, library, resources, and laboratories is good and the problem areas are given close attention and importance. School owners aspire to have an accredited, improved, and center of quality education institution with stable capacity of a financial and logistic resources. There are different problems encountered by the respondents that affect the improvement of the school. These are the problems on enrollment, facilities, library resources, and instructional materials. There are problems that are found very serious and must be given solutions through the school's development plan. There is no significant difference in the responses of the administrators and teachers in terms of development initiatives. A Five-year Continuing Development Program may be used for school's improvement.

Based on the findings and conclusions obtained from this study, the researcher prepared a five-year continuing development program to improve the school's performance, and therefore recommends the following:

\section{A. For the School Administrators}

Undertake and impose the recommended five-year development program prepared by the researcher to improve the school's performance. Use the proposed five-year continuing development program as a guide for future plan and program that is considered as a part of a curriculum improvement. Use the proposed five-year continuing development program as a reference in putting up a school branch. Engage with stakeholders for the school's needs on instructional materials, grants, scholarships, and other related contributions for the benefit of the students.

\section{B. For the Teachers and other School Personnel}

Use the proposed five-year continuing development program as a teachers' reference for the improvement of the students' academic performance. Utilize the plan as a curriculum guide for proper instructions and strategies, and for the NAT review for the students. Recommend related programs and projects concerning the students' academic performance. Implement home visitation to fully monitor the students' curricular and non-curricular performance. Conduct individual and peer guidance and counseling to students for the academic growth.

\section{For the Parents}

Impose guidance and close monitoring to the children and recommend Family Hour of Spiritual Upliftment to respond to the needs of the children. Engage with the school's programs, projects, and activities; and be involved with the children's scholastic activities. Implement monitoring of the children's academic performance. Recommend awareness to activities outside the school to ensure the participation of other stakeholders.

\section{For the Students}

Get involved in the school's programs, projects, and activities. Avail of the Schools' free tutorial and mentoring for the scholastic growth. Seek advice from the parents, teachers, school personnel, and other family members for the solutions of the problems encountered. Advise to monitor the academic performance by submitting quarterly assessment on school performance.

\section{E. For the other Stakeholders}

Tap government and non-government organizations for grants, donations, gifts, and other related contributions for the benefit of the students. Involve private computer institutions and sectors for some computer units and connectivity. Ensure the $100 \%$ awareness on participation and involvement to programs, projects, and activities. Monitor the community linkages for proper documentation and later use as reference to the next programs. Coordinate the programs and projects through proper written communication. 


\section{References}

[1] Sunga, Franklin C., Q \& A on Selected Education Laws and other Regulations for Public and Private Schools and the Annotated 2010 Revised Manual of Regulations for Private Schools as Amended, Philippines, 2013

[2] Brundrett, Mark and Rhodes, Christopher, Leadership for Quality and Accountability in Education, USA and Canada, Routledge, 2011

[3] Cordeiro, Paula A. and Cunningham, William G. Educational Leadership A Bridge to Improved Practice. New Jersey: Pearson Education, Inc., 2013

[4] Delgado, Mario, A Primer on School Community Partnership, DepEd Maguindanao, 2009

[5] Downie, N. M. and Heath, Robert W., Basic Statistical Method, New York, Harper and Row Publishers, 1984
[6] Essex, Nathan L., School Law and the Public Schools, New Jersey USA, Pearson Education Inc. 2012

[7] Fraenkel, Jack R. and Wallen, Norman E. How to Design and Evaluate Research in Education, United States, McGraw-Hill Book Company, 1994

[8] Gray, David L. and Smith, Agnes E., Case Studies in the $21^{\text {st }}$ Century School Administration, California USA, Sage Publication Inc., 2007

[9] Labrador, Vilma et al., Experiential Learning Courses Handbook, Teacher Education Council, DepEd, Pasig Philippines, 2009

[10] Manabat, Aline L. The Making of Villagers Montessori College as a Future University, A Dissertation, New Era University, 2015 